\title{
Determinants of Use of Small-Scale Irrigation and Its Effects on Household Food Security: The Case of Bako Tibe District, West Shoa, Ethiopia
}

\author{
Abera Ifa*, Jema Haji, Jemal Yusuf \\ Department of Rural Development and Agricultural Extension, Haramaya University, Haramaya, Oromia, Ethiopia.
}

\begin{abstract}
How to cite this paper: Abera Ifa, Jema Haji, Jemal Yusuf. (2021) Determinants of Use of Small-Scale Irrigation and Its Effects on Household Food Security: The Case of Bako Tibe District, West Shoa, Ethiopia. International Journal of Food Science and Agriculture, 5(4), 658-669. DOI: $10.26855 /$ ijfsa.2021.12.013
\end{abstract}

Received: September 16, 2021

Accepted: October 12, 2021

Published: November 18, 2021

*Corresponding author: Abera Ifa, Department of Rural Development and Agricultural Extension, Haramaya University, Haramaya, Oromia, Ethiopia.

Email: ifadinkolaas@gmail.com

\begin{abstract}
The livelihood of rural households in Ethiopia depends on agriculture and largely small-scale subsistence oriented and crucially rain-fed. Use of the available water resources for irrigation development is the most promising option to counter the erratic rain and occurrence of drought in the country which makes agricultural production a challenge. The aim of this study is to analyze the determinants of use of small-scale irrigation and its effects on household food security in Bako Tibe district of west Shoa zone. Data were collected from 120 randomly selected household heads (40 users and 80 non-users) from four Kebeles of the district. Both descriptive statistics and econometric model were applied for analyzing data. In the econometric analysis, the determinants of use of small-scale irrigation were identified by the use of binary logit model. Household calorie consumption method was adopted to determine food security status of the sampled households. A result shows that $82.5 \%$ of irrigation users and $37.5 \%$ of non-users are found to be food secure while $17.5 \%$ of the users and $62.5 \%$ of non-users are food insecure. The binary logistic regression model shows that seven variables are found to determine use of small-scale irrigation and the variables are: distance of the irrigation scheme, number of livestock, total annual income, access to market information, age, sex and dependency ratio. In general, the empirical analysis, like many other similar studies, confirms that small-scale irrigation development would have positive effect on food security of beneficiary households. Thus, concerned bodies should join hands to support the development of small-scale irrigation schemes to reduce the food insecurity problem in the study area in particular and the country in general.
\end{abstract}

\section{Keywords}

Bako Tibe, small scale-irrigation, food security, binary logit model, Total income

\section{Introduction}

Ethiopia is the second most populated country in Africa following Nigeria, having 105 million people estimated during 2017 [1]. Displacement induced by intercommunal clashes coupled with drought worsens the food and nutritional insecurity situation in the country and more than 8.1 million people need food assistance during 2019 [2]. Furthermore, 85\% of the Ethiopian population depends on agriculture and live-in rural areas. Farmers in poor areas have suffered from chronic poverty and severe food insecurity being vulnerable to climatic changes and dependent on rain fall. This is mainly attributes to a low level of agricultural productivity. Such low productivity areas are characterized by persistent rural poverty and, increasing population pressure has often resulted in vicious circle of poverty and environmental de- 
gradation [3]. However, the country could not meet its large food deficits through relying on rain-fed agricultural production alone. Adverse climatic change (a series of droughts) combined with rapid population growth, declining land holding size, growing landlessness, environmental degradation, subsistence and rain-fed dependent agricultural production have resulted in a growing problem of drought vulnerability and food insecurity in Ethiopia [4]. The government has designed a comprehensive food security strategy that targets the chronically food insecure especially in highly vulnerable areas: marginal and semi-arid areas that are largely moisture deficient, including pastoral areas, with high population pressure. If such measures can be effectively and sustainably implemented, they can make significant difference [5]. Water for agriculture is increasingly recognized as a major constraint to improve the lives of the rural poor and is an important component of rural livelihood programs that need to be yet strongly established in Ethiopia.

Irrigation is one means by which agricultural production can be increased to meet the growing food demand in Ethiopia. Increasing food demand can be met in one or a combination of three ways: increasing agricultural yield, increasing the area of arable land and increasing cropping intensity (number of crops per year). Expansion of the area under cultivation is a finite option, especially in view of the marginal and vulnerable characteristics of large parts of the country's land and also increasing population. Increasing yields in both rain-fed and irrigated agriculture and cropping intensity in irrigated areas through various methods and technologies are therefore the most viable options for achieving food security in Ethiopia [6].

Ethiopia also endowed 362,590 square kilometers of agricultural land and 15,119,000 hectares of arable land [7]. The country is believed to have the potential of 5.1 million hectares of land that can be developed for irrigation through pump, gravity, pressure, underground water, water harvesting and other mechanisms [8]. During 2005/2006, the total estimated area of irrigated agriculture in the country was 625,819 ha, which, in total, constitutes about $18 \%$ of the potential [9].

It is planned to expand irrigation development in the country by an additional 528,686 hectares by the year 2010 [8-10] which will constitute about 33\% of the potential. In 2005/2006, the total cultivated land area, including the rain-fed area, was about 12.28 million hectares [8]. Hence, the total current irrigated land area accounts for approximately $5 \%$ of the total cultivated land. When the traditional schemes are not considered, the irrigated land area covers a minimum of approximately $1.6 \%$ of the total cultivated area. Currently, the Ethiopian government gives more emphasis to small-scale irrigation as a means of achieving food self-sufficiency [8]. The total irrigated land area in the country is recently increasing and reached 2.4 million ha in 2015 from 885,000 hectares during 2011 and the plan is to increase it to 4 million hectares by2020 [11].

The development of small-scale irrigation is one of the major intervention areas to improve agricultural production and productivity in the rural parts of the country. Irrigation strengthens the base for sustainable agriculture, provides increased food security to poor communities, contributes to the improvement of poor nutrition level and provides a source of household income. Accordingly, in the past few years, the federal and the regional governments of Ethiopia, and donor agencies have been given attention to promoting small-scale irrigation schemes that were targeted to improve the food security of the smallholder farmers [12].

In considering this fact, the regional government has constructed two modern small-scale irrigation schemes in the area and handed them over to the smallholder farmers. In addition, number of traditional irrigations is there in the district. However, most of the predicted beneficiaries do not use the irrigation schemes as expected. Despite a heavy investment in irrigation and availability of water resource, the factors that affect the use of irrigation and its effect on household food security have not been studied yet in the study area. Therefore, this study was conducted to identify the determinants of use of small-scale irrigation that impedes the farmers from using irrigation and its effects on household food security in the study area.

\subsection{Empirical Evidences}

Irrigation development is being promoted by government and non- government organization as one of the development strategies contributing to the overall agricultural development of the country in general and to rural household food security in particular [13]. The study has shown the importance of smallholder irrigation development as a key drought mitigation measure and improvement of household food security through increased agricultural production [14]. The other study indicated that small-scale irrigation schemes are very important in poverty reduction, livelihood enhancement, enhancing food security, especially in recent times when the rainfall pattern is increasingly becoming erratic. This study concluded that food security situation has improved after the completion of the scheme because agricultural related activities became all year round with dry season, providing the necessary ingredients (vegetables) to complement staple foods produced during the rainy season [15]. Kumar [16] also stated that irrigation has contributed significantly in boosting India's food production and creating grain surpluses used as drought buffer.

A study by Hussain, et al. [17] confirms that, access to reliable irrigation water can enable farmers to adopt new technologies and intensify cultivation, leading to increased productivity, overall higher production, and greater returns 
from farming. This in turn opens up new employment opportunities; both on farm and off-farm, and can improve incomes, livelihood, and the quality of life in rural areas. Hussain, et al. [17] identified five key dimensions of how access to good irrigation water contributes to socio-economic uplift of rural communities. These are production, income and consumption, employment, food security, and other social impacts contributing to overall improved welfare. In Ethiopia, a study conducted by Hussain and Hanjra [18] identified that in Tigray irrigated agriculture has benefited some households by providing an opportunity to increase agricultural production through double cropping and by taking advantage of modern technologies and high yielding crops that called for intensive farming and this in turn leads to household food security.

Woldeab Teshome [19] conducted impact assessment study on community managed irrigation schemes on productivity and household income in Weliso and Wenchi districts of Oromiya region through comparing irrigation users and non-users. The finding revealed that contribution of irrigated agriculture to income is about $70 \%$ in the highly irrigated villages as compared to $60 \%$ in two other low irrigated areas. At the same time, the absolute size of agricultural income is also the highest in the highly irrigated village despite the lower landownership size and cultivated holding by more than $30 \%$ over the low irrigated village. The share of agricultural income is also found to increase with the increase in irrigation intensity of the village and the increased income from irrigated agriculture enables the farm households to be food secure.

Irrigation agriculture plays a crucial role in the sustainable livelihood of rural community's improvements in access to irrigation water services is a power full tools to diversify livelihoods and reduce vulnerability of smallholder producer [20]. Hussain, et al. [17] noted that irrigation can benefit the poor through raising yield and production, lowering the risk of crop failure and generating higher and year-round farm. It can enable smallholder to adopt more diversifying cropping pattern and to shift from low value subsistent production to high value market-oriented production, which increase income of households.

Gebremedhin and Peden [21] explain the importance of having sufficient income enable an individual to purchase enough food for household. In many low-income developing countries, agriculture is the main source of income and entitlement for rural families. It is impossible to generalize that only accessing irrigation water by rural poor solves the problem of income shortage and poverty. There are factors like markets, policies and other resources that affect directly or indirectly income and poverty situations of rural household. However, though water is only a single element that play important role in addressing the problems. The following simple conceptual frame work is developed to show how use of irrigation increases household income and reduce poverty. According to Gebremedhin and Peden [21], farm households who have access to irrigation able to increase cash crop production through year rounding cropping since water will be available for crop to grow whenever needed that means risk of crop failure reduced as slighted in WorkichoJateno [13]. At the same time, farmers would increase productivity of cash crops through use of complementary inputs (such as high yield variety seed, fertilizers, pesticides, etc), since irrigation reduces crop failure and therefore raise return to input.

There are other conditions which should be fulfilled among others availability of variable inputs on time, credit service to purchase inputs and provision of appropriate training. Higher production and productivity of high value crop led farmers to fetch high income provided favorable market prices and institutional arrangements are in place. The conceptual frame work also indicates that increased cash income through high value crop production through irrigation increase capacity of household to purchase food crops and also reduces consumption shortfall. Still expenditure pattern should be in favor of purchasing of food crops and at the same time there should be favorable relative price between high value and stable crops.

Increased cash income enables farm household to purchase variable agricultural inputs for subsistence crop production which increase productivity and thereby increase availability of food for consumption at household level. Furthermore, farmers who use irrigation also able to increase their asset base through saving their income in the form of livestock and household asset. In general, the conceptual framework shows how farm households able to generate high income through production of high value crops using irrigation and at the same time, it indicates how income to be generated reduces household vulnerability to food insecurity.

\section{Methodology}

\subsection{Description of study area}

Bako Tibe district is located about 251 and $125 \mathrm{~km}$ from Addis Ababa and Ambo respectively along the main road to the west direction of Ethiopia. The total area of the district is about $644.94 \mathrm{~km}^{2}$. The total population size of the district is 65,293 men and 68,291 women of totally 133,584 with total household size of 22,880. The district comprises 28 rural Kebele Administrations (KAs) each KA has one development center. The district has a wide range of water resource, both traditional and modern irrigation system. Traditional irrigation has a long history in the district. However, modern 
irrigation systems were introduced in the 1980s' by the current regime. The two modern schemes have cemented irrigation channel; a design introduced to reduce water loss trough seepage.

The major agro-ecological zone of the study area is semi-arid, sub-humid, and humid with bimodal rain fall characteristics. The area receives an average of $1,242 \mathrm{~mm}$ rain fall annually and the temperature ranges from $13.3^{\circ} \mathrm{C}(\mathrm{min})$ to $27.9^{\circ} \mathrm{C}(\max )$. The area is characterized by mixed farming system where the major livestock raised are cattle, sheep, goat, equines, and poultry. The average elevation of the area is 1650 m.a.s.l. In the area, $54.25 \%$ of land is arable, $23.98 \%$ is for pastures, and $5.12 \%$ of land is covered by forest and $16.65 \%$ of the land is for infrastructure or other uses.

\subsection{Description of Sample Irrigation Schemes}

The study was under taken in four small-scale irrigation schemes in Bako Tibe district in which 'Laku' and 'Abuko' modern small-scale irrigation schemes were selected purposively and 'Gibe' and 'Jima' traditional small-scale irrigation schemes were selected randomly. The modern schemes are diverted from 'Laku' and 'Abuko' rivers respectively. Laku scheme has the potential to irrigate 72 hectares but currently irrigates 17.6 hectares. The scheme has 88 beneficiary households from Tulu Sangota Kebel Administration. The potential of Abuko scheme is 106 hectares and currently irrigates 31.4 hectares. This scheme has 76 beneficiary household heads from Dembi Dima Kebel Administration. The Gibe traditional scheme has the potential to irrigate 246.81 hectares but currently irrigates 164.61 hectares. The beneficiary households are 349 from Gajo Kui Kebel Administration. The Jima scheme support households in Dembi Gobu Kebel Administration and has 475 beneficiaries. This scheme has the potential to irrigate 59.34 hectares but currently irrigates 39.8 hectares.

\subsection{Data Collection Methods}

Structured questionnaires, focused group discussion and key informant interview were used to collect the data. Issues covered during data collection were demographic features, land endowment and economic sources (irrigated and rain fed and others), livestock ownership and access to service (extension and credit and market information).

Sampling procedures: Two kebele administrations in the study area were selected purposively because of the availability of modern small-scale irrigation. The other two rural kebele administrations were selected by simple random sampling techniques. Then, total numbers of households from each kebele administrations were listed and stratified in to two strata of users and non-users. Simple random sampling techniques were used to select sample respondents from each stratum. Since a number of household heads in each Kebel Administrations were not proportional, probability proportional to sample size was used to determine the number of respondents from each stratum then, simple random sampling technique was used to draw 120 respondents from each stratum. Of the total sample respondents 40 households were users and the remaining household heads were non-users of irrigation.

\subsection{Data Analysis Techniques}

The study used both descriptive and econometric data analysis. Descriptive statistics like mean, standard deviation, and percentages were used to examine and understand the socio- economic situations of the sample households. Moreover, t-test was used to examine the mean difference between irrigation users and non-users with respect to certain continuous variables. For categorical variables, a chi-square test was used to test for association. While econometric analysis is used to identify the determinants of use of small-scale irrigation, the inferential statistics were used to examine the effects of use of irrigation on household food security.

\subsection{Measuring household food security status}

Direct survey of dietary intake at household level and a seven-day recall method was used to measure food security status of households (in comparison with appropriate adequacy norms). The food items consumed by sample households' calorie content was calculated using calorie conversion factor and household members were also converted to their adult equivalent and then, the amounts of total calories consumed by each sample household was computed and divided by seven days to get per day calories consumed by the household. This figure was divided by the Adult Equivalent (AE) of respective households and which finally gave the amount of calorie available per AE for each sampled household. The result was compared with recommended Kcal per adult equivalent per day (2,200 Kcal) which is set by the Ethiopia Government [22]. Thus, those households beyond this threshold level will be deemed to be food secure otherwise not food secure.

\subsection{The logit model}

The linear probability model assumes that the probability of an individual making a given choice is a linear function 
of the individual attributes. But this model has some econometric problems associated with it such as non-normality of the disturbance term, hetroscedastic variance of the disturbance, lower value of $\mathrm{R}^{2}$ and non-sensical predictions (non-fulfillment of $\left.0<\mathrm{E}\left(\mathrm{Y}_{\mathrm{i}} / \mathrm{X}_{\mathrm{i}}\right)<1\right)$ [23]

The logit and probit models guarantee that the estimated probabilities will lie between the logical limit of 0 and 1 . These two binary outcome models have an s-shaped relationship between the independent variables and the probability of an event which addresses the problem with functional form in the linear probability model [23]. The choice between the logit and the probit models is largely one of convenience because the substantive results are generally indistinguishable [24].Therefore, the logit model was used to identify determinants of use of small-scale irrigation. Following [25], the functional form of logit model is specified as follows: $P_{i}=\left(y_{i}=1 / x\right)=1 / 1+e^{-\left(\beta_{0}+\beta_{i} x\right.}$. This equation can be written as: $P_{i}=1 / 1+e^{-z}$ Where: $P_{i}$ is the probability of using irrigation and e represents the base of natural logarithm (2.718) and $Z_{i}$ is the function of $m$ explanatory variables $(x) 1-P_{i}=1 / 1+e{ }_{i}$ is the probability of not using irrigation. Then, the odds ratio in favor of use of irrigation is given by $\mathrm{P}_{\mathrm{i}} / 1-\mathrm{P}_{\mathrm{i}}$. By taking the natural $\log$ of the equation we get the following $L=\ln \left[\mathrm{P}_{\mathrm{i}} / 1-\mathrm{P}_{\mathrm{i}}\right]=\mathrm{Z}$. With the error term incorporated, the logit model will have the following form: $\mathrm{Z}=\beta_{\mathrm{o}}+\beta_{1} \mathrm{x}_{1}+$ $\beta_{2} x_{2}+\beta_{3} x_{3}+\ldots \beta_{n} x_{n}+U$ Where $x_{1}, x_{2}, x_{3} \ldots x_{n}$ are the explanatory variables of the model, $\beta_{0}$ is the intercept $\beta_{1}, \beta_{2} \ldots \ldots$ $\beta_{\mathrm{n}}$ are the coefficients to be estimated in the model and $\mathrm{U}$ is the error term.

\section{Results and discussion}

\subsection{The survey results of continuous variables}

The results of descriptive statistics in Table 1 show that the distance of irrigation scheme from the residence of farmers, the number of livestock holding and total income of sample households affect the use of irrigation at 1 percent significance level. Furthermore, the results in Table 1 show that there was no significant relation between the use of irrigation and dependence ratio of household heads. As indicated in Table 1, the average dependency ratio of sample households is 0.35 which depicts that every hundred persons within the economically active population groups supported not only themselves but also additional 35 economically inactive persons with all basic necessities. Contrary to the expectation, there was no relationship between the age of household heads and the use of irrigation. This indicates that the young, active labor force has the greater motives to adopt new production technologies, whereas, older household heads gave their irrigable land to their younger descendent and became non-users.

The mean land holding size of the sample household head in table 1 is 1.55 hectares. Significantly more land as a basic input for farming in the study area was held by users of irrigation than by non-users. As indicated in Table 1, the mean land holding for users of irrigation is 1.7 hectares and the corresponding figure of land holding for non-users is 1.4 hectares. This result indicates that there was a significant association between the use irrigation and land holding size at 10 percent probability level. In addition to more land holding, users of irrigation were involved in rearing livestock which is the source income.

As indicated in table 1, the mean livestock holding in TLU for the sample respondents is 7.2. Irrigation user households have a better livestock holding than non-user households which enables them to increase their financial ability to purchase variable inputs for agricultural production by use of irrigation and leads to household food security. The study result revealed that there was a significant association between use of irrigation and number of livestock holding. The mean livestock holding for irrigation user is 9.77 TLU and that of non-users is 5.94 TLU.

The average number of oxen owned by the user of irrigation was $1.60( \pm 0.71)$ oxen, whereas of non-user of irrigation is 1.78 ( \pm 0.87$)$. It was also revealed that from the total sampled household heads 9.2 percent of households owned no ox, 21.7 percent owned one ox, 60 percent owned two oxen and 2.5 percent owned more than two oxen. The t-test result shows that mean difference in oxen holding was found to be statistically insignificant (see Table1).

Sample household head's total annual income in the study area is not only depends on the agricultural potential and the relative price obtained by the farmers for agricultural produce and livestock and livestock products, but also on the time of sale and the type of off-farm activities a household performs like providing mule cart service. In the study area, as it is observed from the survey results, the relative share of income from cereal to the total annual household income is the largest. Hence, cereal production is the most important source of income in the study area. It is followed by vegetable production, livestock production, and off-farm activities respectively. The average household annual income per $\mathrm{AE}$ of the sample households was found to be 1780.51 birr with minimum and maximum birr 247 and 6,549 respectively. The maximum and minimum total annual income of users is 6,549 birr and 888.89 birr per AE respectively and the corresponding figure for non-users is 3,130.12 birr and 246.8 birr per AE respectively. As indicated in Table 1, the households' mean total annual income per AE of user is 2,708.30 $( \pm 1,312.59)$ birr. However, the mean total annual income per AE of non-user of irrigation is 1,316.61 ( \pm 630.59$)$ birr. The t-test result shows that there was significant difference in total annual income of household per AE between the users and non-users at 1percent significance level. This indicated that the gap between the two groups is highly considerable and shows that the user earns more annual income 
per AE than the non-user which is obtained from cropping intensity.

The average distance between the residences of framers and the irrigation scheme in kilometer had the implication of use of irrigation water. As indicated in Table 1, the average distance of users' residence is $1.3( \pm 0.55) \mathrm{km}$; the corresponding figure of non-user is $4.3( \pm 4.53) \mathrm{km}$. The t-test result reveals that there was a statistically significant relation between the two groups at 1 percent probability level. This indicates that the distance between the household's residents affect the use of irrigation.

Table 1. Descriptive statistics for continuous variables

\begin{tabular}{cccccccc}
\hline \multirow{2}{*}{ Variable } & \multicolumn{2}{c}{ Users $\mathbf{( N = 4 0 )}$} & \multicolumn{2}{c}{ Non- users $\mathbf{( N = 8 0 )}$} & \multicolumn{2}{c}{ Total (120) t-test } \\
& Mean & SD & Mean & SD & Mean & SD & \\
\hline FMLSZ & 4.51 & 0.95 & 4.73 & 1.01 & 4.62 & 0.98 & 1.20 \\
HEADAGE & 42 & 9.4 & 44.4 & 9.2 & 43.2 & 9.3 & 1.15 \\
DEPRATIO & 0.35 & 0.22 & 0.35 & 0.23 & 0.35 & 0.22 & -0.96 \\
DISSCHEME & 1.3 & 0.55 & 4.3 & 4.53 & 2.8 & 2.54 & $4.18^{* * *}$ \\
LIVSTOCNO & 9.77 & 3.13 & 5.94 & 2.77 & 7.86 & 2.95 & $-6.83^{* * *}$ \\
OXEN & 1.6 & 0.71 & 1.78 & 0.87 & 1.69 & 0.79 & 1.10 \\
CULTLAND & 1.70 & 0.76 & 1.4 & 0.79 & 1.55 & 0.76 & $-1.89 *$ \\
TINCOME & $2,708.30$ & $1,312.59$ & $1,316.61$ & 630.59 & $2,012.50$ & 971.59 & $-7.84^{* * *}$ \\
\hline
\end{tabular}

Source: survey result (2014), *, **, *** indicate significance level at 10\%, 5\%, 1\% respectively.

\subsection{The Survey Results of Dummy Variables}

As indicated in Table 2, the survey result showed that 15.8 percent of the sample households are headed by females and the rest 84.2 percent are headed by male. Out of the total sample household heads interviewed 33.3 percent were irrigation users and 66.7 percent were non-users of irrigation. According to the result, 25 percent of irrigation users are female headed and the rest 75 percent are male headed and the corresponding figure of female and male headed for non-user is 11.25 percent and 88.75 percent respectively. The chi-square test $\left(\chi^{2}=3.78\right)$ shows that there is statistically significant difference between those household heads that are the users of irrigation and non-users in terms of their sex at 10 percent probability level and this indicates male headed households were more likely to be irrigation users than female headed households (see Table 2).

The descriptive statistics result shows that 44.2 percent of the sample household heads were found to be illiterate; whereas 55.8 percent of the sample household heads were literate. The comparison by use of irrigation indicates that 9 irrigation users and 44 non-users are found to be illiterate and 31 irrigation users and 36 non-users are literate. According to the survey result, 22.5 percent of irrigation user and 55 percent of non-users of irrigation were illiterate and 77.5 percent of users and 45 percent of non-users were literate in the study area. The chi-square test $\left(\chi^{2}=11.42\right)$ shows that there was a significant relationship between use of irrigation and level of education at 1percent probability level (see Table 2).

According to the study result, 39.2 percent of the sample households were not getting extension services. When we compare irrigation user and non-user households, majority of the user households gets better support from extension agents than non-users in the study area. According to the survey 29 (72.5\%) users and 44 (55\%) non-users get extension service and 11 (27.5\%) and 36 (45\%) users do not access extension service. The development agents provide advice, training, demonstration on how to use technologies and distribution of inputs for agricultural production. The result of chi-square test $\left(\chi^{2}=3.42\right)$ indicated that there was significant relationship between use of irrigation and access to extension service at 10 percent probability level (see Table 2 ).

As indicated in Table 2 access to market information, the survey result shows 64.2 percent of the sample households have access to market information and the rest sample have no access to market information. When we compare irrigation user and non-user households, majority of the user households get market information than non-user. According to the survey, 34 (85\%) users and 43 (53.8\%) non-users get market information and the corresponding figure that shows no market information of users and non-users is $6(15 \%)$ and $37(46.2 \%)$, respectively. The chi-square test result $\left(\chi^{2}=13.33\right)$ indicates that there was statistically significant relationship between the use of irrigation and access to market information at 1 percent probability level. The households who have more information of a market price are more 
eager to use irrigation farming to increase their income which in turn makes them food secure.

The main source of credit in the study area is micro finance institute. As indicated in Table 2, out of the sample households heads, 60.8 percent get credit while 39.2 percent do not take credit due to various reasons. The comparison by use of irrigation showed that 30 (75\%) users and 43 (53.75\%) non-users take credit. From irrigation users of sample household heads, 25 percent of the sample respondents and from the non-user 46.25 percent households said that they do not take credit and complained for its high interest rate. The chi-square test result $\left(\chi^{2}=5.05\right)$ revealed that there was a relationship between access to credit and use of irrigation at 5 percent probability level (see Table 2).

Table 2. The chi-square test for dummy (discrete) variables

\begin{tabular}{ccccccc}
\hline Variable definition & Categories & User & Non-user & Total & Percent & $\chi^{2 \text {-test }}$ \\
\hline HEADSEX & $1=$ male & 30 & 71 & 101 & 84.2 & $3.78^{*}$ \\
& $0=$ Female & 10 & 9 & 19 & 15.8 & \\
HEADEDU & $1=$ literate & 31 & 36 & 67 & 55.8 & $11.42^{* * *}$ \\
& $0=$ Illiterate & 9 & 44 & 53 & 44.2 & \\
HEALTHHHH & $0=$ no & 31 & 62 & 93 & 77.5 & 0.00 \\
ACCCREDIT & $1=$ yes & 9 & 18 & 27 & 22.5 & \\
ACCEXT & $0=$ no & 10 & 37 & 47 & 39.2 & $5.05^{* *}$ \\
& $1=$ yes & 30 & 43 & 73 & 60.8 & \\
ACCMKT & $0=$ no & 11 & 36 & 47 & 39.2 & $3.42^{*}$ \\
& $1=$ yes & 29 & 44 & 73 & 60.8 & \\
& $0=$ no & 6 & 37 & 43 & 35.8 & $11.33^{* * *}$ \\
& $1=$ yes & 34 & 3 & 77 & 64.2 & \\
\hline
\end{tabular}

Source: Survey Result (2014). *, **, *** indicate significance level at $10 \%, 5 \%, 1 \%$ respectively.

The descriptive statistics shows that the mean annual expenditure of the household heads per AE is 1,645.45 birr. The mean differences of annual expenditure per AE of the user of irrigation and no-user of irrigation is 2,347 $( \pm 1141)$ and 1,295.2 $( \pm 740.83$ ) birr respectively (see Table 3 ). When we compare the mean annual expenditure per AE between the users and non-users, the users expend more money than non-users. The result of t-test indicates that households' expenditure per AE between the two groups is statistically significant at 5 percent probability level. The descriptive statistics indicated that the annual total crop production of users was higher than non-users of irrigation because of the cropping intensity (frequency of crop production within a year) used by users of irrigation.

The mean annual crop production of the sample household is 5,928.5 $( \pm 3,258.7) \mathrm{kg}$ and the range varies between $400 \mathrm{~kg}$ and $18,000 \mathrm{~kg}$. As indicated in Table 3, average annual production for irrigation user household is 6,667.25kg $( \pm$ $4,468) \mathrm{kg}$ while the annual average production of non-user is $3,567.5( \pm 1,702.2) \mathrm{kg}$. The mean difference of annual total production between the user and non-user of irrigation is statistically significant at 1 percent probability level.

Table 3. Annual expenditure per AE in Birr and total farm production in kg of households

\begin{tabular}{|c|c|c|c|c|c|c|}
\hline & \multicolumn{2}{|c|}{ Users $(\mathrm{N}=40)$} & \multicolumn{2}{|c|}{ Non-users $(\mathbf{N}=\mathbf{8 0})$} & \multirow[b]{2}{*}{ Total } & \multirow[b]{2}{*}{ t-test } \\
\hline & Mean & SD & Mean & SD & & \\
\hline Total production (kg) & $6,667.25$ & 4,468 & $3,567.5$ & $1,702.2$ & $10,234.75$ & $-5.48 * * *$ \\
\hline Annual expenditure (birr) & 2,347 & 1,141 & $1,295.20$ & 740.83 & $3,642.2$ & $-6.08^{* *}$ \\
\hline
\end{tabular}

Source: survey result (2014). 


\subsection{Food Security Status of Sample Households}

The study grouped farm households into food secure and insecure. Based on the descriptive statistics result obtained, the users were food secure than non-user of irrigation. In addition, food secure and food insecure sample households were seen after the daily energy intake of household per adult equivalent was calculated using seven days back of energy intake of households and compared the result obtained with the minimum subsistence energy requirement of 2,200 kcal per AE per day. Following this procedure, 62.5 percent of non-users and 17.5 percent of users were found to be food insecure respectively and 37.5 percent of non-users and 82.5 percent of the users were food secure. Out of 120 sample households, 52.5 percent of them were food secure and 47.5 percent of them were food insecure (see Table 4 ). However, the use of irrigation for agricultural production is the most crucial variables that influence the food security status of households in the area.

Table 4. Food security status of households

\begin{tabular}{ccccccc}
\hline & \multicolumn{2}{c}{ Users } & & \multicolumn{2}{c}{ Non-users } & \multicolumn{2}{c}{ Total } \\
Food security & Number & percent & Number & percent & Number & percent \\
\hline Food secured & 33 & 82.5 & 30 & 37.5 & 63 & 52.5 \\
Food insecure & 7 & 17.5 & 50 & 62.5 & 57 & 47.5 \\
Total & 40 & 100 & 80 & 100 & 120 & 100 \\
\hline
\end{tabular}

Source: survey result (2014).

\subsection{Effect of Irrigation on Food Security of the Households}

The descriptive statistics revealed that the mean food energy intake of the total sample households per adult equivalent per day is 2,655 kcal with maximum and minimum 4,976.5 and 1,446.5 kcal per AE per day, respectively. As indicated in Table 5, the mean food energy intakes per AE per day of irrigation users and no-users are 3,446.98 ( \pm 866.7$)$ and 2,297.09 $( \pm 604.8) \mathrm{kcal}$ respectively. The result of t-test showed that the mean difference of food energy intake per AE per day is statistically significant at 1 percent probability level. In addition, the survey result obtained from focus group discussion and key informant interview, the participation in irrigation farming enables households to produce twice a year which is substantial for intake of food energy required and hence use of irrigation improves food security status of household.

Table 5. Food energy intake per AE/day of households

\begin{tabular}{cccccc}
\hline $\begin{array}{c}\text { Food energy in- } \\
\text { take/AE/day }\end{array}$ & \multicolumn{2}{c}{ Users } & Non-users & t-test \\
\hline & Mean & St.dev & Mean & St.dev & \\
kcal per AE/day & $3,446.98$ & 866.7 & $2,297.09$ & 604.8 & $-8.45^{* * *}$ \\
\hline
\end{tabular}

Source: Survey result (2014).

\subsection{Econometric Analysis}

The goodness of fit confirmed that the model fit the data. The value of Pearson chi-square test showed that the overall goodness of fit of the model significant at one percent probability level. This indicates the model's estimate fit the data at an acceptable level. The other measure of goodness of fit in the logistic regression model is measured by count $\mathrm{R}^{2}$, which works on the principle that if the predicted probability of the event is greater than 0.50 , the event will occur otherwise the event will not occur [24]. The overall prediction of the model is found to be $95 \%$ which is greater than 0.50 .

\subsection{The maximum likelihood estimates of binary logit model results}

The model result in Table 6 showed that age of the household head had a significant negative effect on the use of irrigation water. This may be because the use of irrigation is labor intensive and exhaustive work that the older household heads cannot bear. In another way, the negative sign indicates that younger farmers use irrigation more than the aged farmers. The odd ratio indicates the use of irrigation decreases by a factor of 0.712 as the age of farmers increases by 1 year. Previous research result also indicated a similar negative effect of age of household heads in adopting new irrigation technology [26]. 
Distance of farm household head's residence had a significant negative effect on the use of irrigation water. Ceteris paribus, the odds of participation in irrigation by household heads decreases by a factor of 0.014 , as the distance of household head's residence from irrigation scheme increases by $1 \mathrm{~km}$ (see Table 6). The household heads that live near the irrigation scheme have more chance to use irrigation water than those household heads that far from irrigation water because households near the irrigation scheme do not incur additional costs of transportation and traveling time. This result is consistent with [27]. Distance of irrigation schemes from the residence of farmers affects the use of irrigation at 1 percent probability level.

Binary logit model result in Table 6 showed that the sex of household head had significant negative effect on the use of irrigation. This result was inconsistent with the prior expectation. This means that the female headed households were more likely to use irrigation than male headed households; this may be because of government policy which allowed the women equal access to asset and extension service. Holding other factor constant, odds ratio in favor of use of irrigation decreases by a factor of 0.016 as the household head becomes male. This result is similar with the result found by [28].

According to the binary logit model result showed in Table 6, dependence ratio variable has significant negative effect on the use of irrigation water. The negative relation of dependency ratio of the household indicates that keeping other variables constant, the odds ratio in favor of use of small-scale irrigation decreases by a factor of 0.001 as the dependence ratio of household increase by one person. Based up on the result, if the households have more dependent labor forces, the less chance he has to use irrigation than the households who have less dependent age groups or economically inactive groups ( $\leq 15$ and $\geq 64$ ages). This result is consistent with findings of [29] which states that members of holdings with high dependency ratios might not be able to participate in programs and projects due to time, labor and/or financial constraints.

The model result indicated in Table 6 shows that access to market information had significant positive effects on the use of irrigation water. The positive relation of this variable indicates that the probability of use of irrigation water by household head is higher when they have access to market information than those household heads that have no access to market information. Households with large livestock holding could obtain more income from the sale of live animals, animal products and renting. Moreover, increased availability of crop residues in irrigated land improves the productivity of livestock where higher livestock holding directly contributed to household income.

As indicated in Table 6, the number of livestock holding by household heads has significant positive effects on the use of irrigation water. The positive relationship indicates that households with larger livestock holding may have income to spend on any possible costs to use irrigation. In addition to the provision of traction power of livestock, they serve as the source of income and food. Considering this contribution of livestock to sustainable supply of food to the households they motivate the adoption of new technology. Hold other factors constant the odds ratio in favor of use of small-irrigation increase by a factor of 5.125 for each increase in one TLU (see Table 6). The same result was reported by $[28,30]$. This shows that holding livestock has influence on the adoption of new technology in different areas.

The binary logit model result in Table 6 showed that the total annual income per adult equivalent has significant positive effects on the use of irrigation water at 5 percent probability level. Household income from different aspects determine the purchasing power of the household with the prevailing price, so that those households having higher total annual income per adult equivalent are more likely to become the user of small-scale irrigation than those households who have less annual income per adult equivalent which in turn leads to household food security. The total incomes earned by household enable them to purchase different variable agricultural inputs and technologies used in irrigation farming to increase the production and productivity.

Table 6. The maximum likelihood Estimates of binary logit model

\begin{tabular}{cccccc}
\hline Variables & B & S.E & Wald & Sig. & Exp(B) \\
\hline FMSZAE & -1.160 & 0.907 & 1.634 & 0.201 & 0.314 \\
AGEHEAD & $-0.340^{* *}$ & 0.135 & 6.367 & 0.011 & 0.712 \\
DEPRATIO & $-6.628^{*}$ & 3.427 & 3.741 & 0.053 & 0.001 \\
SEXHEAD & $-4.154^{*}$ & 2.285 & 3.305 & 0.069 & 0.016 \\
HEADEDU & -0.702 & 1.359 & 0.267 & 0.605 & 0.496 \\
HEALTHHH & 1.020 & 1.563 & 0.426 & 0.514 & 2.772 \\
ACCCREDT & 0.351 & 1.564 & 0.050 & 0.823 & 1.420 \\
ACCEXT & -0.171 & 1.192 & 0.021 & 0.886 & 0.843 \\
\hline
\end{tabular}




\begin{tabular}{cccccc}
\hline & & & & & \\
\hline ACCMKT & $7.188^{* * *}$ & 2.552 & 7.931 & 0.005 & 132.3 \\
DISSCHEME & $-4.258^{* * *}$ & 1.525 & 7.796 & 0.005 & 0.014 \\
LIVTOCKNO & $1.634^{* * *}$ & 0.568 & 8.267 & 0.004 & 5.125 \\
OXEN & -0.436 & 0.997 & 0.191 & 0.662 & 0.647 \\
CULTLNDSZ & 0.232 & 0.643 & 0.130 & 0.718 & 1.262 \\
TINCOMEHH & $4.333^{* *}$ & 2.029 & 4.561 & 0.043 & 76.148 \\
Constant & -2.056 & 8.154 & 0.064 & 0.801 & 0.128 \\
\hline
\end{tabular}

Notes: Pearson chi-square $121.864 * * *$ count $\mathrm{R}^{2}=95 \%$

-2loglikilihood ratio $30.900, * * *, * *$ and $*$ indicate statistically significant at $1 \% .5 \%$ and $10 \%$ probability level respectively. Source: model output.

\section{Discussion}

Based on the evidence from the field the study was conducted to identify different factors that significantly affect the probability of use of irrigation farming as well as the effects of use of irrigation farming on household food security. The study identified seven explanatory variables that are considered to determine the use of irrigation farming. These variables are: age of household head, dependency ratio, access to market information, number of livestock, total income, and distance of the scheme from household residence and sex of household head. From 40 user households considered, the research finding indicated that 82.5 percent of the households were food secure and the rest 17.5 percent were food insecure. However, 62.5 percent of farm households were food insecure from 80 non-users of irrigation and the rest 37.5 percent were food secure. In general, from 120 sampled households in the study area 52.5 percent were food secure and the rest 47.5 percent were food insecure. According to the key informant interview and focus group discussion conducted during survey with supplementary tools revealed that irrigation users are in a better position in different aspects when compared with those who do not use irrigation farming in food security. This may be because the users have large annual income per adult equivalent, large size of cultivated land and large size of livestock holding, these all contributed significantly to a better food security status of households in the study area.

\section{Conclusions and Recommendations}

Balancing investment in access to (credit and extension service, market information) plays a significant and direct role in the use of irrigation water. Number of livestock owed, access to market information and total income of households were critical in having a positive impact on the use of irrigation water and this in turn have significant positive effect on household food security. The rearing of livestock enables the farm households to use irrigation. This could be through sales of livestock and income generation for any possible spending in the use of irrigation farming. In addition, livestock production improves the financial status of households and in turn this will leads to food security of households. Therefore, strategy should avoid problems that hinder livestock rearing like fodder, disease and etc. and encourage farmers to rear livestock in intensive care for diversified purpose.

The distance of the schemes from the household's residences, the age and the sex of household is also significant variables which affect the use of irrigation water negatively. The findings of the research indicated that the more near the residences of the farmers to the schemes, the more chance the households have to use irrigation. Based up on the findings, the study suggested that the concerned body should consider the distance of household residences during scheme construction for better use of irrigation water. There is evidence for the need to strengthen the economic capability of female-headed households through improving access to irrigation water.

Sex of the household head had a negative relationship with the use of irrigation. This indicated that female- headed households were user of irrigation than male headed households. Therefore, female-headed households should be given attention and provide equal participation with male headed households on the use of irrigation water and adoption of new technology. Moreover, female-headed households should be empowered and given equal access to resource since they have capacity to perform adopted technology. Households with younger, more active labor force had aspiration to adopt new production system, whereas, older household heads handed over their irrigable land to their younger descendent and became non-users. This might be because the use of irrigation water is capital and labor intensive. Thus, concerned body should encourage and assist younger household heads and provide training on technology use.

Access to market information is positively determined the use of irrigation. This indicates that an increase in price for fruits and vegetables motivates households to use irrigation water for production. The allover impression was that improving access to market information could be required to motivate the users to allocate more land for irrigation farming. Thus, the policy should set strategies through which information related to a price of agricultural products will be 
disseminated easily.

\section{References}

[1] World Bank. (2019). An Overview of Ethiopian Economy. World Bank’s goals of promoting rapid economic growth and improving service delivery.

[2] FAO. (2019). Early Warning Early Action report on food security and agriculture (April-June 2019). Rome. P. 62. License: CC BY-NC-SA 3.0 IGO.

[3] Von Braun, J., Fan, S., Meizen-Dick, R., Rosgrant, M. W., Pratt, A. N. (2008). International agricultural research for rood security, poverty reduction, and the environment. In Stansbury, C. (ed.)., what to expect to from scaling up CGIAR investment and “Best-Bet” Programs. International Food Policy Research Institute (IFPRI), Washington, DC., USA. pp. 35-36.

[4] TassewWoldehana. (2004). The Experiences of Measuring and Monitoring Poverty in Ethiopia. A Paper Presented for the Inaugural Meeting of the Poverty Analysis and Data.

[5] Awulachew, S. B., Merrey, J. D. (2005). Assessment of Small-Scale Irrigation and Water Harvesting in Ethiopian Agricultural Development [abstract]. International water management institute: Colombo, Sri Lanka.

[6] IWMI (International Water Management Institution). (2005). Experience and Opportunity for Promoting Small-Scale/Micro Irrigation and Rain Water Harvesting For Food Security in Ethiopia. Working Paper 98. Addis Ababa, Ethiopia.

[7] CIA World Fact Book. (2019). Ethiopia-United States Central Intelligence Agency. https://www.cia.gov/library/publications/ the-world-factbook/geos/et.html

[8] MoFED (Ministry of Finance and Economic Development). (2010). Trends prospects for meeting MDGs by 2015, millennium development goal report. [Internet]. [cited 2011 July 4]. Addis Ababa, Ethiopia. Available from: http//www.dagethiopia.org.

[9] MoWR (Ministry of Water Resources). (2006). Five Year Irrigation Development Programmme (2005/06-2009/10). Addis Ababa, Ethiopia: MoWR. P. 57.

[10] Atnafu, T. (2007). Current and Future Plans of Irrigation and Drainage Development in Ethiopia. Irrigation and Drainage Development Studies Department. Ministry of Water Resources. Addis Ababa.

[11] ATA. (2016). Ethiopian Agricultural Transformation Agency Annual Report. Addis Ababa, Ethiopia.

[12] Abdissa, F., Tesema, G., Yirga, C. (2017). Impact Analysis of Small-Scale Irrigation Schemes on Household Food Security the Case of Sibu Sire.

[13] WorkichoJateno. (2007). Contribution of Small-Scale Irrigation to have Household Food Security and Income: The Case of Koro Irrigation Schem, Arsi, Zone. Unpublished M.A Thesis Presented at School of Graduate of Haramaya University.

[14] Lemma Dinku. (2004). Small Holders’ Irrigation Practices and Issue of Community Management: The Case of Two Irrigation Schemes in East Oromia. Ethiopia. An MSc Thesis Presented to the School of Graduate Studies of Addis Ababa University. P. 116.

[15] Bogsan, E. and Kuude. (2013). Assessment of a Small-scale Irrigation Scheme on Household Food Security and Leisure in Kokoligu; Ghana.Vol. 3, No. 1.

[16] Kumar, D. (2003). Food Security and Sustainable Agriculture in India. Pp. 1-2. The Water Management Challenge. Working Paper 60. International Water Management Institute. Colombo, Sri Lanka.

[17] Hussain, I., RegassaNamara, and S. Madar. (2004). Water for Food Security for the Poor. pp. 85-86. A Collection of a thematic papers. Asian Development Bank. Colombo, Srilanka. Indicators and Measurements. A Technical Review. UNICEF, New York and IFAD, Rome. Initiative (PADI). Mombassa, Kenya.

[18] Hussain, I., Hanjra, M. A. (2004). Irrigation and Poverty Alleviation: Review of the Empirical Evidence, IWMI. Irrigation and Drainage, 53: 1-15.

[19] Woldeab Teshome. (2003). Irrigation Practices, State Intervention and Farmers Life-Worlds in Drought-Prone Tigray. Pp. 2-53. PhD Dissertation, Wageningen University, the Netherlands.

[20] Desta Beyera. (2004). Impact of Community Managed Irrigation Scheme on Farm Production Efficiency and Household Food Security: The Case of Weliso and Wechi Districts of Ormia Region. An MSc Thesis Presented to the School of Graduate Studies of Alemaya University. P. 107.

[21] Gebremedhin, B. and D. Peden. (2003). "Policies and Institutions to Enhance the Impact of Irrigation Development in Crop-Livestock Mixed Systems.” In McCornik, P. G., A. B. Kamara and G. Taddesse (eds.). "Integrated Water and Land Management Research and Capacity Building Priorities for Ethiopia.”Proceedings of a MoWR/EARO/IWMI/ILRI International Workshop Held at ILRI, Addis Ababa, Ethiopia, 2-4 December, 2002. IWMI.

[22] Abebaw Shimelis. (2003). Dimension and Determinants of Food Security Among Rural Household in Dire Diwa Area, Easter Ethiopia. An MSc Thesis Presented to the School of Graduate Studies of Haramaya University. P. 121. 
[23] FSS (Food Security Strategy). (2002). The Federal Democratic Republic of Ethiopia, Addis Ababa, Ethiopia.

[24] Long, S. (1997). Regression Models for Catagoricalc and Limited Dependent Varaiables v. Sage Publications, Inc. London. Pp. 35-83.

[25] Madalla, G. S. (1983). Limited Dependent and Qualitative Variables in Econometrics. Pp. 260-285. Cambridge University Press, United Kingdom.

[26] Gujirati, D. N. (1995). Basic Econometrics. 3rd ed. McGraw-Hill Co., New York.

[27] Phoeb Koundouri, Celina Nauges, and Vangelis Tzouvelekas. (2000). Endogenous Technology Adoption Under Production Risk: Theor and Application to Irrigation Technology.

[28] Abonesh Tesfaye. (2006). The Impact of Small-Scale Irrigation on Household Food Security and Assessment of its Management System: The Case of Filinto and Godino Irrigation Scheme in Ada Liban District East Showa Zone. An M.Sc. Thesis Presented to the School of Graduate Studies of Haramaya University. P. 123.

[29] Yenetila. (2007). Factors Influencing The Use of Irrigation Water at Gedeb Irrigation Scheme: The Case of Machakel Woreda, East Gojam Zone. An M.Sc. Presented to the School of Graduate Studies, Haramaya University.

[30] FAO (Food and Agricultural Organization of the United Nations). (2010). Agricultural Populations and Households, Agri-Gender Statistics Toolkit: Data Items, Accra, Ghana.

[31] Mesfin Astetkei. (2005). Analysis of Factors Influencing adoption of Triticale (x-TriticosecaleWitmack) and its Impact: The Case of Ferta Woreda. An M.Sc. Thesis Presented to the School of Graduate Studies of Haramaya University. P. 112. 